\title{
EVALUACIÓN DE LA PERSISTENCIA DE ANTICUERPOS EN HEMBRAS BUFALAS (BUBALUS BUBALIS) LUEGO DE LA VACUNACION CON BRUCELLA ABORTUS CEPA 19. RESULTADOS PRELIMINARES
}

\author{
Jacobo, R.A. ${ }^{1}$, Stamatti, G. M. ${ }^{1}$, Storani, C. A. ${ }^{1}$, \\ De Sa Da Silva, A. ${ }^{1}$, Cipolini, M. F. ${ }^{1}$ \& Martinez, D. E. ${ }^{1}$
}

\begin{abstract}
RESUMEN
Con el objetivo de evaluar la persistencia de aglutininas posteriores a la vacunación con Brucella abortus $\mathrm{C} 19$ en búfalas hembras, se realizó un seguimiento serológico a 50 bubillas de 4 a 8 meses en dos establecimientos de cría. En uno de ellos el 34\% todavía tenían anticuerpos vacunales detectados por las técnicas de BPA y SAT, y el 26\% en el segundo, controladas hasta los 6 meses luego de haber sido aplicada la vacuna. Respecto al 2ME, en ambos rodeos el $6 \%$ de los animales mantenían aglutininas hasta esa edad, detectadas por esta técnica.
\end{abstract}

Palabras claves: Sanidad en búfalos, Brucelosis en búfalos, Vacuna C19, Corrientes (Argentina).

\section{SUMMARY}

\section{Serologic study young buffaloes females vaccinated with Brucella abortus C19.}

A serologic study was carried out to verify effect duration of agglutinins after the vaccination with Brucella abortus S19 in young buffaloes females aged from 4 to 8 months in two breeding farms. In one of them, the $34 \%$ have showed vaccine antibodies detected by the techniques of BPA and Serum agglutination test (SAT) and the $26 \%$ in the other one, up to six months after the vaccination. In relation to 2 Mercaptoethanol (2ME) technique in both farmes, the $6 \%$ of the animals have supported agglutinins up to 6 months after vaccination.

Key words: Buffaloes, Health, Brucellosis, Vaccine, Corrientes (Argentina).

1.- Cátedra de Enfermedades Infecciosas, Facultad de Ciencias Veterinarias, UNNE.

Sargento Cabral 2139.(3400) Corrientes. E-mail: enfinf@vet.unne.edu.ar

Manuscrito recibido el $1^{\circ}$ de marzo de 2004 y aceptado para su publicación el 14 de junio de 2004 . 